\title{
Sodium Meta-Autunite Colloids: Synthesis, Characterization, and Stability
}

\author{
Zuoping Zheng* Jiamin Wan Tetsu K. Tokunaga \\ (Lawrence Berkeley National laboratory, One Cyclotron Road, Berkeley, CA 94720)
}

\begin{abstract}
Waste forms of U such as those in the United States Department of Energy's Hanford Site often contain high concentrations of $\mathrm{Na}$ and $\mathrm{P}$. Low solubility sodium uranyl phosphates such as sodium meta-autunite have the potential to form mobile colloids that can facilitate transport of this radionuclide. In order to understand the geochemical behavior of uranyl phosphate colloids, we synthesized sodium meta-autunite colloids, and characterized their morphology, chemical composition, structure, dehydration, and surface charge. The stability of these synthetic plate-shaped colloids was tested with respect to time and $\mathrm{pH}$. The highest aggregation rate was observed at $\mathrm{pH} 3$, and the rate decreases as $\mathrm{pH}$ increases, indicating that higher stability of colloid dispersion under neutral and alkaline $\mathrm{pH}$ conditions. The synthetic colloids are all negatively charged and no isoelectric points were found over a $\mathrm{pH}$ range of 3 to 9 . The zeta-potentials of the colloids in the phosphate solution show a strong $\mathrm{pH}$-dependence in the more acidic range over time, but are relatively constant in the neutral and alkaline $\mathrm{pH}$ range. The geochemical behavior of the synthetic colloids can be interpreted using DLVO theory. The results suggest that formation of mobile sodium meta-autunite colloids can enhance the transport of $U$ in some contaminated sediments.
\end{abstract}

Key Words: Uranium; Sodium Meta-Autunite; Colloids; Zeta Potential; Transport

\footnotetext{
${ }^{*}$ Corresponding author.

E-mail address: zzuoping@lbl.gov (Z.Zheng)
} 


\section{Introduction}

Radionuclide colloids are a great concern in waste storage safety because of their potential migration in subsurface environments [1-4]. High-level radioactive wastes in the 200 Area of the U.S. Department of Energy (DOE) Hanford Site contain U at about $0.5 \mathrm{lb} / \mathrm{gal}(\sim 0.25 \mathrm{M})$. Major ionic components in wastes contained in Hanford tanks such as BX-102 consist of $2.9 \mathrm{M} \mathrm{Na}, 0.53 \mathrm{M}$ nitrate, $0.64 \mathrm{M}$ carbonate, $0.36 \mathrm{M}$ phosphate, and $0.23 \mathrm{M}$ sulfate [5]. Given such an extreme chemical composition, it is expected that these wastes contain large quantities of stable colloids, because colloid formation is often observed in environments with high degrees of mineral supersaturation. The significance of colloids in waste solutions and in contaminated subsurface environments are not well understood, and their potential importance in enhanced contaminant transport necessitates research into this phenomenon.

Uranyl phosphates have been previously investigated to understand mechanisms of uranium fixation because of their low solubility and high stability under aerobic conditions [6-7]. Among the many known uranyl phosphates, autunite $\left(\left\{\left(\mathrm{X}^{1-2+}\right)_{2-1}\left[\left(U O_{2}\right)\left(\mathrm{PO}_{4}\right)\right]_{2} \cdot x \mathrm{H}_{2} \mathrm{O}\right\}\right)$ is an important group because of its low solubility. The variety of autunite phases are complicated by a wide range of cation and anion substitutions, and by varying degrees of hydration [7]. Formation of nanometer-scale uranyl phosphate crystals (Saleeite: Mg autunite) at Koongarra U deposit, Australia, was observed to result from the local saturation conditions [8]. Bencheikh-Latmani et al. [9] reported the formation of an autunite-like phase resulting from $\mathrm{U}$ interacting with phosphate released from cell death and lysis release. The procedures reported in the 
literature for synthesizing autunite are mostly based on ion exchange from chernikovite $\left(\left[\mathrm{H}_{3} \mathrm{O}\right]_{2}\left[\left(\mathrm{UO}_{2}\right)\left(\mathrm{PO}_{4}\right)\right]_{2} \cdot 6 \mathrm{H}_{2} \mathrm{O}\right)[10-13]$. The resulting autunite particles are usually large ( $>10$ microns) [13]. In order to obtain colloid-scale autunite, an alternative method is needed.

The effectiveness of colloid transport strongly depends on the stability of colloids in aqueous solutions. The stability of colloids is determined by the combined effects of their density, size, surface charge, solution chemistry, and solid-solution interfacial tension [1]. Colloidal stability has been studied for decades and a variety of approaches have been used including single particle detection methods [14], turbidimetry [15-16], optical absorbance [17], and dynamic light scattering [18-21]. Accurately predicting and understanding the stability of colloids, however, still remains a challenge because of relatively small and varied colloid size as well as surface charge of the colloids. According to Derjaguin-Landau-Verwey-Overbeek (DLVO) theory, the stability of colloids in aqueous solutions is determined by two interaction energies, van der Waals attraction and interparticle repulsion. The stability of colloid suspensions is ensured by a high repulsive barrier (energy) between particles, which is constrained by $\mathrm{pH}$, ionic strength, as well as time (e.g., [20, 22-24]).

The objectives of this work are (i) to develop a new procedure to synthesize sodium meta-autunite colloids $\left(\mathrm{Na}_{2}\left(\mathrm{UO}_{2}\right)_{2}\left(\mathrm{PO}_{4}\right)_{2} \cdot 6 \mathrm{H}_{2} \mathrm{O}\right)$. (ii) to characterize the synthesized colloids. (iii) to determine the stability of the colloidal suspension influenced by $\mathrm{pH}$ and time (iv) to apply classical DLVO theory to interpret the stability of the colloidal suspension. 


\section{Materials and methods}

\subsection{Chemicals}

All chemicals used are analytical grade. Water used was distilled and de-ionized water $(\sim 18 \Omega)$. Phosphate $(640 \mathrm{mM})$ and uranyl $(100 \mathrm{mM})$ stock solutions were prepared with concentrated phosphoric acid, $\mathrm{H}_{3} \mathrm{PO}_{4}$ (J.T.Baker) and crystalline uranyl nitrate, $\mathrm{UO}_{2}\left(\mathrm{NO}_{3}\right)_{2} \cdot 6 \mathrm{H}_{2} \mathrm{O}$ (Alfa Aesar), respectively.

\subsection{Synthesizing Sodium Metal-Autunite Colloids}

Sodium meta-autunite colloids were synthesized by: mixing $0.5 \mathrm{mM}$ uranyl nitrate, $\mathrm{UO}_{2}\left(\mathrm{NO}_{3}\right)_{2} \cdot 6 \mathrm{H}_{2} \mathrm{O}$, with $40 \mathrm{mM} \mathrm{H}_{3} \mathrm{PO}_{4}$, then adjust the $\mathrm{pH}$ to 5.0 with $0.1 \mathrm{M}$ $\mathrm{NaOH}$. The pH 5 was chosen for two reasons: (i) it yields supersaturation of sodium meta-autunite; and (ii) it minimizes formation of U(VI)-carbonate complexes that would dominate the speciation at $\mathrm{pH}>6.5$ [25]. The solution was then aged for 10 days in a temperature-controlled water bath at $70{ }^{\circ} \mathrm{C}$. No effort was made to control the fugacity of $\mathrm{CO}_{2}$. The pale yellow precipitation can be obtained after centrifugation $(12,000 \mathrm{rpm}$ for $60 \mathrm{~min}$ ). The chemical reaction responsible for sodium meta-autunite formation is as follows.

$2 \mathrm{Na}^{+}+2 \mathrm{PO}_{4}^{3-}+2 \mathrm{UO}_{2}^{2+}+\mathrm{xH}_{2} \mathrm{O} \rightarrow \mathrm{Na}_{2}\left(\mathrm{UO}_{2}\right)_{2}\left(\mathrm{PO}_{4}\right)_{2} \cdot \mathrm{xH}_{2} \mathrm{O}$

\subsection{Stability Experiments}

After aging for 10 days, the colloid suspension was transferred directly from a $500-\mathrm{mL}$ beaker into seven $50-\mathrm{mL}$ vials. The $\mathrm{pH}$ in the vials was adjusted to $3,4,5,6,7$, 8, and 9 by adding $0.1 \mathrm{M} \mathrm{H}_{3} \mathrm{PO}_{4}$ acid or $0.1 \mathrm{M} \mathrm{NaOH}$, then sealed. The solution $\mathrm{pH}$ was periodically monitored and no marked changes in $\mathrm{pH}$ were observed during the whole experimental period. The vials were continuously agitated on a shaker at room 
temperature $\left(23{ }^{\circ} \mathrm{C} \pm 1{ }^{\circ} \mathrm{C}\right)$. Samples were taken periodically for measuring changes in aqueous uranium concentration, colloidal size, and zeta potential ( $\zeta)$. The total experiment lasted over two months.

\subsection{Determining Aqueous Uranium Concentrations}

The aqueous phase was separated by centrifugation (12,000 rpm for 60 minutes) and analyzed for $\mathrm{U}$. Aqueous $\mathrm{U}$ concentrations were determined using a Kinetic Phosphorescence Analyser (KPA) (Model KPA-11, Chemchek Instruments, Richland, Washington), with a detection limit of $0.1 \mathrm{ppb}$. Analytical U concentrations were determined with reference to calibration standards in dilute nitric acid $\left(1 \% \mathrm{HNO}_{3}\right)$. The $\mathrm{U}$ in colloidal fraction is estimated by difference between the initial $\mathrm{U}$ concentration and dissolved U fraction.

\subsection{Characterizing Sodium Meta-Autunite Colloids}

High resolution transmission electron microscopy (HRTEM) and energydispersive X-ray (EDX) (CM 200, Philips) analyses were used to characterize morphology, structure, and elemental composition of the colloids. A particle-sizer (CPS Disc Centrifuge, CPS Instrument, Inc.) was used to determine colloid-size distribution. Compared to other techniques for determining particle size such as light scattering (1821), The CPS has marked advantages. Firstly, it can determine particle-size distributions for bulk samples with high resolution using very small suspension volumes $(0.1 \mathrm{~mL}$ samples needed for analysis). Secondly, It can provide more information including particle numbers of varied particle sizes simultaneously. The validated range of the particle-size determined by CPS is from $20 \mathrm{~nm}$ to $30 \mu \mathrm{m}$. Colloid-size distributions for individual samples were determined relative to a calibration standard. The mean colloid 
diameter, $\bar{R}$, was calculated with respect to the relative mass distribution of the colloids obtained from CPS.

$\bar{R}=\frac{\sum F_{i} r_{i}}{\sum F_{i}}$

where $\mathrm{F}$ refers the relative mass for a colloid diameter (r).

In order to obtain information on structural water in the synthesized sodium metaautunite colloids, thermogravimetric analysis was conducted on an air-dried sample (SDT 2960 Simultaneous DTA-TGA, TA Instrument, Inc.). A heating rate of $2{ }^{\circ} \mathrm{C} / \mathrm{min}$ was chosen with $\mathrm{Al}_{2} \mathrm{O}_{3}$ as a reference. Zeta potentials $(\xi)$ of the colloids were determined with a Coulter DELSA 440 SX (Coulter, Miami, FL). Measurements were conducted at: frequency range: $500 \mathrm{~Hz}$; electric field strength: varied relative to the solution ionic strength (if ionic strength is over $0.01 \mathrm{M}$ ); on time: $2.5 \mathrm{~s}$ and off-time $0.5 \mathrm{~s}$; run time: $60 \mathrm{~s}$. A mobility standard of carboxylate-modified polystyrene latex particles in $0.01 \mathrm{M}$ sodium phosphate buffer at $\mathrm{pH} 7$ was periodically used to check stability of the DELSA instrument. The $\zeta$ values for the selected samples were also measured on a ZetaSizer 4 (Malvern) for comparison, and are fairly comparable (Table 1).

\subsection{Thermodynamic Calculations}

Equilibrium thermodynamic calculations were conducted to constrain concentration ranges for both uranium and phosphate in order to yield sufficient supersaturation with respect to sodium meta-autunite phase. The $\mathrm{pH}$-dependent solubility of sodium meta-autunite was calculated in both phosphate solutions and distilled water systems exposed to the atmospheric $\mathrm{CO}_{2}$ pressures, and an activity diagram was constructed. The calculations were conducted with the geochemical computer code 
PHREEQC 2.0 [26] using the database from Lawrence Livemore National Laboratory (thermo.com.V8.R6.230) in addition to the updated uranium database from the Nuclear Energy Agency [27]. The thermodynamic data for the sodium meta-autunite, however, were selected from Water4f.dat [28] because of availability.

\subsection{DLVO Theory Calculations}

The DLVO theory is often used to describe interparticle forces of colloids as the sum of the attractive van der Waals forces and the repulsive electrostatic forces [29]. The total energies of interaction per unit area between two plates can be expressed as a function of $\mathrm{h}$, the distance between the plate surfaces [30].

$$
\Phi=64 k_{B} T n_{\infty} \kappa^{-1} \Psi_{0}^{2} \exp (-h \kappa)-\frac{A}{12 \pi}\left(\frac{1}{h^{2}}+\frac{1}{(h+2 \delta)^{2}}-\frac{2}{(h+\delta)^{2}}\right)
$$

where $\mathrm{k}_{\mathrm{B}}$ is the Boltzmann constant, $\mathrm{T}$ is the Kelvin temperature, $\mathrm{n}$ is the number of ions related to molar concentration as $n_{\infty}=1000 M_{i} N_{A}$ (M is the molar concentration, $\mathrm{N}_{\mathrm{A}}$ is a Avogadro's number), $\delta$ is the thickness of the plates, $\Psi$ is a parameter related to the surface potential $\psi$, given by

$$
\Psi=\left[\exp \left(z e \psi / 2 k_{B} T\right)-1\right]\left[\exp \left(z e \psi / 2 k_{B} T\right)+1\right]
$$

where $\mathrm{z}$ is the ion charge and $\mathrm{e}$ is the electron charge, and $\mathrm{K}^{-1}$ is the Debye-Huckel length. This length is expressed as:

$$
\kappa^{-1}=\left[\frac{1000 e^{2} N_{A}}{\varepsilon k_{B} T} \sum_{i} Z_{i}^{2} M_{i}\right]^{-\frac{1}{2}}
$$

where $\varepsilon$ is the dielectric parameter, and $\mathrm{A}$ is the Hamaker constant. It is normally assumed that $\psi$ and $\zeta$ are similar, in particular at low $\zeta$ values [31]. Based on the DLVO 
theory, colloidal suspensions are predicted to be more stable with increased values of calculated interaction energies [32].

\section{Results and discussion}

\subsection{Synthesis and Characterization of the Synthetic Sodium Meta-Autunite Colloid 3.1.1. Colloid Morphology, Composition, Structure, and Size Distribution}

Fig.1 shows a HRTEM image of synthesized sodium meta-autunite colloids. The synthetic colloids are tetragonal thin plates with major axes lengths in the range of $\sim 70$ to $\sim 250 \mathrm{~nm}$. The discrete particle electron diffraction pattern shown in Fig. 1 indicates the $\mathrm{d}$ value of the strongest intensity is $3.41 \AA$, with the best match to the main $\mathrm{d}$ value of $3.50 \AA$ of sodium meta-autunite [33]. The d values of $2.1 \AA, 2.54 \AA$, $3.31 \AA$, and $4.5 \AA$ are obtained, which also agree well with the main d values of sodium meta-autunite [33]. As shown in Fig. 1b, the EDX spectra of the colloids are characterized by U-P-Na. The elemental compositions are relatively homogeneous in the detected area of sample. Three lines of evidence (diffraction pattern, elemental composition, and morphology), confirm that the colloids synthesized are sodium meta-autunite. It should be noted that the colloids are very sensitive to damage by the HRTEM beam. Beam damage causes transformations of the crystalline colloids to amorphous forms within seconds. The collapse of the structure is presumably associated with the removal of $\mathrm{H}_{2} \mathrm{O}$ from the interlayer of the particles as discussed later.

Colloidal size distribution in bulk suspensions measured using the CPS Disc Centrifuge is presented in Fig. 2. The colloids synthesized yield a relatively narrow size distribution. The synthetic colloids show thin plate morphology (Figure 1). To assess 
influence of colloid shape on the particle-size distribution, a sensitivity analysis was performed. Based on the approach of Perrin (presented in Hiemenz and Rajagopalan [30]), we calculated sedimentation friction factors by approximating our particles as oblate ellipsoids with the ratio of particle length to thickness varied from 10 to 200 . The unit cell thickness $(1.00 \mathrm{~nm})$ constrains the upper limit of these ratios [35]. The resulting particle-size distributions (Fig. 2) are consistent with the TEM images (Fig. 1).

\subsubsection{Dehydration Property}

Autunite phases can undergo rapid dehydration under ambient conditions [36], and water content strongly impacts the stabilization of the autunite structure. Based on the TGA data and formula of the sodium meta-autunite $\left(\mathrm{Na}_{2}\left(\mathrm{UO}_{2}\right)_{2}\left(\mathrm{PO}_{4}\right)_{2} \cdot \mathrm{xH}_{2} \mathrm{O}\right)$, the loss of $\mathrm{H}_{2} \mathrm{O}$ (x) with temperature can be accurately estimated. The results, as shown in Fig. 3, indicate five dehydration steps with a total 6.4 water molecules lost of the synthetic sodium meta-autunite in the whole temperature range tested. In particular, in the range of $26{ }^{\circ} \mathrm{C}$ (starting temperature point) to $40{ }^{\circ} \mathrm{C}$, the decrease of water corresponds to a loss of 2.5 molecules $\mathrm{H}_{2} \mathrm{O}$. This could be part of reason for the collapse of the structure as observed during HRTEM measurements. Similar TGA data were obtained for the synthetic hydrogen autunite [12]. An endothermic peak at $65^{\circ} \mathrm{C}$ (a loss of 3 molecules $\mathrm{H}_{2} \mathrm{O}$ ) and gradual endothermic decrease was reported between $125{ }^{\circ} \mathrm{C}$ and $200{ }^{\circ} \mathrm{C}$ (a loss

of one molecule $\mathrm{H}_{2} \mathrm{O}$ ). Similar water molecule contents for other meta-autunite members, chernikovite $\left(6 \mathrm{H}_{2} \mathrm{O}\right)$ and meta-ankoleite $\left(6 \mathrm{H}_{2} \mathrm{O}\right)$ [12], have been reported. Recently, Wellman et al. [6] synthesized 6 molecular $\mathrm{H}_{2} \mathrm{O}$ sodium meta-autunite particles.

Autunite structures are characterized by the autunite-type sheet formed by the sharing of vertices between uranyl square bipyramids and phosphate tetrahedral, with 
composition $\left[\left(\mathrm{UO}_{2}\right)\left(\mathrm{PO}_{4}\right)\right]^{-}$[37]. The interlayer contains $\mathrm{Ca}$ or $\mathrm{Na}$ atoms coordinated by several $\mathrm{H}_{2} \mathrm{O}$ groups. Hence, autunite phases are normally characterized by tetragonal morphology, including autunite $\left(\mathrm{Ca}\left(\mathrm{UO}_{2}\right)_{2}\left(\mathrm{PO}_{4}\right)_{2} \cdot \mathrm{xH}_{2} \mathrm{O}\right)$, and meta-autunite group Chernikovite, meta-ankoleite $\left(\mathrm{K}_{2}\left(\mathrm{UO}_{2}\right)_{2}\left(\mathrm{PO}_{4}\right)_{2} \cdot 6 \mathrm{H}_{2} \mathrm{O}\right)$, sodium meta-autunite [11,12]. Because the retention of water is very sensitive to temperature, the loss of water during HRTEM will influence the interlayer configuration and hydrogen bonding, leading to the collapse in crystal structure.

\subsection{The Stability of the Synthetic Sodium Meta-Autunite Colloids}

\subsubsection{Colloid Dissolution with Time and $\mathrm{pH}$}

The mass percentage of the sodium meta-autunite colloids formed from the synthetic solution after ten days of aging shows that $>95 \%$ of the total U initially added was in the colloidal fraction. Calculations of the synthetic solution speciation indicate that U-P complexes were predominant ( $>95 \%$ of total $\mathrm{U}$ complexed with $\mathrm{P}$, and remaining species are mainly hydroxy complexes). Figure 4 shows a plot of calculated activity ratio of the $\mathrm{HPO}_{4}^{-2} / \mathrm{HCO}_{3}{ }^{-}$as a function of $\mathrm{pH}$. Nearly all our samples are located in the solubility area of sodium meta-autunite, indicating that sodium meta-autunite is most likely the stable phase in the $\mathrm{pH}$ range of $3 \sim 9$. The high ratio of $\mathrm{HPO}_{4}{ }^{2-} / \mathrm{HCO}_{3}{ }^{-}$ ensures that a large variety of aqueous U-P complexes dominate, leading to the preferential formation of sodium meta-autunite phase (38). The high concentration of $\mathrm{P}$ coordinated with $\mathrm{U}$ implies that $\mathrm{U}$ would be bound to $\mathrm{P}$ during the synthetic process and would eventually inhibit development of a pure schoepite phase. Previous research [39] indicates that the dissolved phosphate to carbonate ratio is the most important factor in controlling the formation of uranyl phosphate phases, because the presence of high 
dissolved carbonate can suppress formation of uranyl phosphate such as chernikovite. Saturation indices were negative for other possible U-bearing phases including schoepite $\left(\mathrm{UO}_{3} \bullet 2 \mathrm{H}_{2} \mathrm{O}\right), \beta-\mathrm{UO}_{2}(\mathrm{OH})_{2},\left(\mathrm{UO}_{2}\right)_{3}\left(\mathrm{PO}_{4}\right)_{2} \bullet 4 \mathrm{H}_{2} \mathrm{O}, \mathrm{UHPO}_{4} \bullet 4 \mathrm{H}_{2} \mathrm{O}$, and $\mathrm{UO}_{2} \mathrm{CO}_{3}$.

During a 69-day dissolution experiment with synthetic sodium meta-autunite in the phosphate solution as a function of $\mathrm{pH}$, aqueous uranium concentrations were the highest at $\mathrm{pH} 3$ and the lowest at $\mathrm{pH} 9$ (Fig. 5a). Compared with the solubility curve of sodium meta-autunite calculated using the experimental conditions, aqueous $\mathrm{U}$ concentrations measured are lower in acidic $\mathrm{pH}$ range (3 4) but higher in the $\mathrm{pH}$ range of $5 \sim 9$, indicating that the colloidal suspension is far from equilibrium. Below $\mathrm{pH} 4.2$, the synthetic solution is under-saturated with respect to sodium meta-autunite. It is thus expected that colloid dissolution at $\mathrm{pH}<4.2$, and further colloid formation at $\mathrm{pH}>5$ will occur over time.

In order to estimate how stable the colloids are in groundwater, the air-dried sodium meta-autunite colloids was mixed with distilled water at an equivalent total $\mathrm{U}$ concentration of $0.5 \mathrm{mM}$. The aqueous $\mathrm{U}$ concentration and $\zeta$ measurements were conducted overnight. The results compared well with equilibrium calculations, as shown in Fig. 5b. The differences between the measured and calculated U concentrations likely reflect a kinetic control on dissolution.

\subsubsection{Time and $p H$ Dependence of Colloid Aggregation}

Colloid size distributions in suspensions as a function of time were measured using CPS for different $\mathrm{pH}$ systems $(3 \sim 9)$. The mean measured colloid sizes are presented in Fig. 6. Colloid aggregation rates for different $\mathrm{pH}$ systems were fairly different as indicated by the slopes of the curves (Fig. 6). The initial aggregation rate is 
the fastest at $\mathrm{pH} 3$, and decreased at higher $\mathrm{pH}$. Depending on the colloid aggregation rate, colloids began to settle out of solution with time. The colloids were immediately resuspended in aqueous solution when shaken, but they quickly settled out again when left undisturbed. At low $\mathrm{pH}$, the colloids aggregate because of van der Waals attraction. However, at higher $\mathrm{pH}$, the colloids are negatively charged and they collide much less frequently and less effectively, owing to the increasingly similar charges of the colloids.

\subsubsection{Zeta Potential (६)}

The zeta potentials of the colloids synthesized were measured in two supporting solution systems, phosphate solution and distilled water in order to understand how solution chemistry affects electronic properties of colloids. The measured $\mathrm{pH}$-dependence of $\zeta$ values of the colloidal suspension is presented in Fig. 7a for various times (up to 69 days). The $\zeta$ values were all negative through the measured $\mathrm{pH}$ range (3 to 9 ). The $\zeta$ values are constant with time in the neutral to alkaline $\mathrm{pH}$ range. However, in the acidic $\mathrm{pH}$ range the $\zeta$ values increases with time, with the larger increases at the lower $\mathrm{pH}$. For comparison, measured $\zeta$ values for the colloids in distilled water versus $\mathrm{pH}$ are shown in Fig. $7 \mathrm{~b}$. Although the $\zeta$ values were all negative through the $\mathrm{pH}$ range measured, the $\zeta$ values show a clear $\mathrm{pH}$-dependence in the acidic $\mathrm{pH}$ range.

A systematic variation in $\zeta$ values with time in the low $\mathrm{pH}$ systems likely results from the successive protonation of $\left[\mathrm{UO}_{2} \mathrm{PO}_{4}\right]^{-}$groups present in the surface structures forming the sheet layers of the sodium meta-autunite particles [11]. $\mathrm{Na}^{+}$competes with $\mathrm{H}^{+}$for coordination sites of $\left[\mathrm{UO}_{2} \mathrm{PO}_{4}\right]^{-}$, reflecting changes in $\zeta$ values. Vochten and Deliens [11] measured $\zeta$ for the well-crystalline hydrogen autunite $\left(\mathrm{HUO}_{2} \mathrm{PO}_{4} \bullet 4 \mathrm{H}_{2} \mathrm{O}\right)$ and meta-autunite $\left(\mathrm{Ca}\left(\mathrm{UO}_{2} \mathrm{PO}_{4}\right)_{2} \cdot 7 \mathrm{H}_{2} \mathrm{O}\right)$ with a diameter ranging from $2 \mu \mathrm{m}$ to $3 \mu \mathrm{m}$. Both 
were characterized by high negative values and sensitive to the $\mathrm{pH}$ at $30{ }^{\circ} \mathrm{C}$, similar to the trend observed in our experiments (Fig. 7a and b). The mobility was due to the crystal structure of the minerals, which consists of negative charged $\left(\mathrm{UO}_{2} \mathrm{PO}_{4}\right)_{\mathrm{n}}{ }^{\mathrm{n}}$-layers on which cations $\left(\mathrm{H}^{+}\right.$at low $\left.\mathrm{pH}\right)$ are bound [11].

High magnitude $\zeta$ values favor the double-layer repulsion and stability of colloidal suspensions [20]. Goldberg et al. [40] determined $\zeta$ values of tuff from Yucca Mountain and found that at $\zeta$ values between 0 and $\pm 30 \mathrm{mV}$, the colloids precipitated; only at $\zeta>1301 \mathrm{mV}$ were they stable. The data on the stability shown in Fig. 6 and $\zeta$ values shown in Fig. 7a indicate that these colloidal suspensions are stable at neutral to alkaline $\mathrm{pH}$. In addition, a long time period is needed to fully develop the charge properties of the colloids.

\section{3..2.4. Interaction Energy between Colloids}

The interaction energy of colloids for the different $\mathrm{pH}$ colloidal suspensions as a function of the surface-to-surface distance was calculated for the parallel plate orientations in Fig. 8. The Hamaker constant is assumed to be $5 \mathrm{k}_{\mathrm{B}} \mathrm{T}$ based on [30], and for the surface potentials, the experimental values for $\zeta$ are used. The plate thickness used is $3.0 \mathrm{~nm}$ based on HRTEM observations. The measured ionic strength ranging from $0.01 \mathrm{M}$ to $0.05 \mathrm{M}$ was used in calculating $\Phi$ for different colloid suspensions. It is clearly seen that interaction energy is a function of both $\mathrm{pH}$ and time. Initially, the energy barrier is the same for all the different $\mathrm{pH}$ colloidal suspensions (Fig. 8a). At low pH, the energy barrier eventually becomes relatively low, allowing aggregation of particles (Fig. 8b). In contrast, at high $\mathrm{pH}$, the energy barrier remains at a high level, allowing the colloid suspension to remain stable (Fig. 8b). 


\section{Conclusions}

A procedure for synthesizing sodium meta-autunite colloids was developed. The synthesized colloids were tetragonal plates with a mean size $\sim 100 \mathrm{~nm}$. The diffraction indexes and composition data indicate that colloids synthesized are sodium metaautunite. Thermal properties of the colloids synthesized are characterized by 6.4 molecular water.

The stability of synthetic sodium meta-autunite colloids strongly depend on time and $\mathrm{pH}$. The colloids tend to aggregate, to varying degrees, for different $\mathrm{pH}$ systems, but are stable under the neutral-alkaline $\mathrm{pH}$ conditions. The colloids are all negative charged and no isoelectric points were observed in the $\mathrm{pH}$ range of $3 \sim 9$. $\mathrm{pH}$-dependent $\xi$ with time was observed for the phosphate solution in acidic $\mathrm{pH}$ range. Relative constant $\zeta$ values were observed for both media in the neutral-alkaline $\mathrm{pH}$ range.

The results of this research have important environmental implications for the fate and transport of radionuclide contaminants in the subsurface. Under appropriate conditions uranium together with phosphate and sodium can form sodium uranyl phosphate colloids such as sodium meta-autunite. The formation of negative charged $\mathrm{U}$ colloids compromises the effectiveness of their removal through filtration during transport through sediments.

\section{Acknowledgements}

This work was carried out under U.S. Department of Energy Contract No. DE-AC0376SF-00098. This research was supported by the Basic Energy Science Program of the Office of Science, U.S. Department of Energy. The authors thank X.Song (LBNL) for providing the HRTEM and TGA analysis. 


\section{References}

[1] J.F. McCarthy, J.M. Zachara, Environ. Sci. Technol. 23 (1989), 496-502.

[2] J.N. Ryan, M. Elimelech, Colloids Surf. A 107 (1996), 1-56.

[3] A.B. Kersting, D.W. Efurd, D.L. Finnegan, D.J. Rokop, D.K.Smith, J.T. Thompson, Nature 397(1999), 56-59.

[4] R. Artinger, T. Rabung, J.I. Kim, S. Sachs, K. Schmeide, K.H. Heise, G. Bernhard, H. Nitsche, J. Contam. Hydrol. 58 (2002), 1-12.

[5] T.E. Jones, B.C. Simpson, N.I. Wood, R.A.Corbin, Preliminary inventory estimates for single-shell tank leaks in B, BX, and By tank farms, RPP-7389 (2001).

[6] D.W.Wellman, J.Icenhower, Goldschmidt Conference (2002), abstract.

[7] P.C. Burns, Rev. Mineral 38(1999), 23-90.

[8] T. Murakami, T. Ohnuki, H. Isobe, T. Sato, Am. Miner. 82(1997), 888-899.

[9] R.Bencheikh-Latmani, J.O. Leckie, J.R.Bargar, Environ. Sci. Technol 37(2004), 3555-3559.

[10] A.G. Sowder, S.B. Clark, R.A. Fjeld, J. Radioanal. Nucl. Chem. 248 (2001),517524.

[11] R.Vochten, M. Deliens, Phys. Chem. Minerals 6(1980), 129-143.

[12] R.Vochten, Amer. Mineral. 75 (1990), 221-225.

[13] L. Van Haverbeke, R.Vochten, K. van Springel, Mineral. Magazine 60 (1996), 759766.

[14] H. Holthoff, A. Schmitt, A. Fernández-Barbero, M. Borkovec, M.A. CabrerízoVílchez, P. Schurtenberger, R. Hidalgo-álvarez, J. Colloid Interface Sci. 192(1997), 463-470.

[15] M. Quesada-Pérez, J. Callejas-Fernández, R. Hidalgo-Álvarez, J. Colloid Interface. Sci. 217(1999), 177-185.

[16] Y. Li, L.J. Ding, H. Nakamura, K. Nakashima, J.Colloid Interface Sci. 264 (2003), 561-564.

[17] R.C. Plaza, A. Quirantes, A.V. Delgado, J. Colloid Interface. Sci. 252(2002), 102108.

[18] D. Sohn, P.S. Russo, A. Davila, D.S. Poche, M.L. McLaughlin, J. Colloid. Interface. Sci. 177 (1996), 31-44.

[19] R. Kretzschmar, H. Holthoff, H. Sticher, J. Colloid. Interface. Sci. 202(1998), 95103.

[20] B.M.I. van der Zande, J.K.G. Dhont, M.R. Bohmer, A.P. Philipse, Langmuir 16 (2000), 459-464.

[21] J.C. Thomas, B.J. Crosby, R.I. Keir, K.L. Hanton, Langmuir 18 (2002), 4243-4247.

[22] X. Feng, E.C. Buck, C. Mertz, J.K. Bates, J.C. Cunnane, D.J. Chaiko, Radiochim Acta. 66/67 (1994), 205-213.

[23] H. Geckeis, B. Grambow, A. Loida, B. Luckscheiter, E. Smailos, Radiochim. Acta 82/83 (1998), 123-128.

[24] D.J. Wronkiewicz, J.K. Bates, S.F. Wolf, E.C. Buck, J. Nucl. Mater. 238 (1996), 7895.

[25] D. Langmuir, Aqueous Environmental Geochemistry. Upper Saddle River, N.J.

Prentice Hall (1997). 
[26] D.L. Parkhurst, C.A.J. Appelo, U.S. Geol.Surv. Wat.Resour.Inv. 99-4259(1999).

[27] R. Guillaumont, T.Fanghanel, J. Fuger, I. Grenthe, V. Neck, D.A. Palmer, M.H. Rand, F.J. Mompean, M. Illemassene, C. Domenechi-Orti, Update on the Chemical Thermodynamics of Uranium, Neptunium, Plutonium, Americium, and Technicium. Elsevier, Amsterdam (2003).

[28] J.W. Ball, D.K. Nordstrom, U.S. Geol. Surv. Open-File Report 91-183 (1991).

[29] J. Israelachvili, Intermolecular \& Surface Forces. Academic Press (1993).

[30] P.Z. Hiemenz, R. Rajagopalan, Principles of Colloid and Surface Chemistry. Marcel Dekker, Inc (1997).

[31] D.R.E. Snoswell, J. Duan, D. Fornasiero, J. Ralston, J. Phys. Chem. B. 107 (2003), 2896-2994.

[32] J.L. Ortega-Vinuesa, A. Martín-Rodríguez, R. Hidalgo-Álvarez, J.Colloid Interface Sci. 184 (1996), 259-267.

[33] JCPDS-ICDD, International Centre for Diffraction Data. New Town Square, PA (1999).

[34] M.B. McBride, P. Baveye, Soil Sci. Soc. Am. J. 66 (2002), 1207-1217.

[35] J.L. Jambor, J. Puziewirz, A.C. Roberts, Am. Min. 80 (1995), 1329.

[36] A.G. Sowder, S.B. Clark, R.A. Fjeld, Radiochim Acta 74 (1996), 45-49.

[37] P.C. Burns, M.L. Miller, R.C. Ewing, Can. Miner. 34 (1996), 845-880.

[38] A. Sandino, J. Bruno, Geochim. Cosmochim. Acta. 56 (1992), 4135-4145.

[39] C.C. Fuller, J.R. Bargar, J.A. Davis, M.J. Piana, Environ. Sci. Technol. 36 (2002), $158-165$.

[40] M.M. Goldberg, J.K. Basco, D.L. Bowers, E.C. Buck, M.A. Clark, J.W. Emery, J.R. Falkenberg, R.J. Finch, J.A. Fortner, L.D. Hafenrichter, C.J. Mertz, Y. Tsai, S.F. Wolf, Argonne National Laboratory Internal Report (2001). 


\section{Figure Captions}

Figure 1. Synthetic sodium meta-autunite colloids formed at $70{ }^{\circ} \mathrm{C}$. a. HRTEM image; b. EDX spectrum. The inset in Figure 1a shows a diffraction pattern from a selected area within the sample.

Figure 2. Influence of particle shape on particle size distribution measured using CPS. The b/a ratio indicates the ratio of the particle length to the particle thickness.

Figure 3. TGA curve for the synthetic sodium meta-autunite (mole $\mathrm{H}_{2} \mathrm{O}$ lost as a function of temperature).

Figure 4. Activity diagram showing the stability field of sodium meta-autunite at $25{ }^{\circ} \mathrm{C}$. Conditions for this diagram: $\sum \mathrm{U}=0.1 \mathrm{mM}, \sum \mathrm{P}=40 \mathrm{mM}, \mathrm{P}_{\mathrm{CO} 2}=10^{-3.5}$ bar.

Figure 5. The aqueous $\mathrm{U}$ concentrations with time for different $\mathrm{pH}$ colloid systems. (a) .phosphate solution; (b) distilled water. The curves represent equilibrium U concentration with respect to sodium meta-autunite calculated using PHREEQC 2.0.

Figure 6. The mean colloid size with time for the different $\mathrm{pH}$ colloidal suspensions as a function of $\mathrm{pH}$

Figure 7. The measured zeta potential (६) with time for the different $\mathrm{pH}$ colloidal suspensions.

(a). phosphate solution; (b). distilled water

Figure 8. The net interaction energy $(\Phi)$ as a function of the distance between particles (h), for the colloidal suspensions. a : day $0 ; \mathrm{b}:$ day 69.

\section{Table Captions}

Table $1 . \zeta$ values by using different instruments

\begin{tabular}{|l|l|l|}
\hline Sample & $\zeta(\mathrm{mV})^{\mathrm{a}}$ & $\zeta(\mathrm{mV})^{\mathrm{b}}$ \\
\hline Mobility Standard & $-39 \pm 11$ & $-51 \pm 10$ \\
\hline AT1 & $-41 \pm 4$ & $-41 \pm 10$ \\
& $-41 \pm 4$ & $-38 \pm 10$ \\
\hline AT7 & $-35 \pm 7$ & $-36 \pm 5$ \\
& $-34 \pm 10$ & $-37 \pm 4$ \\
\hline
\end{tabular}

a. Malvern (The zetasizer nano series)

b. The Coulter Delsa 
Figure 1

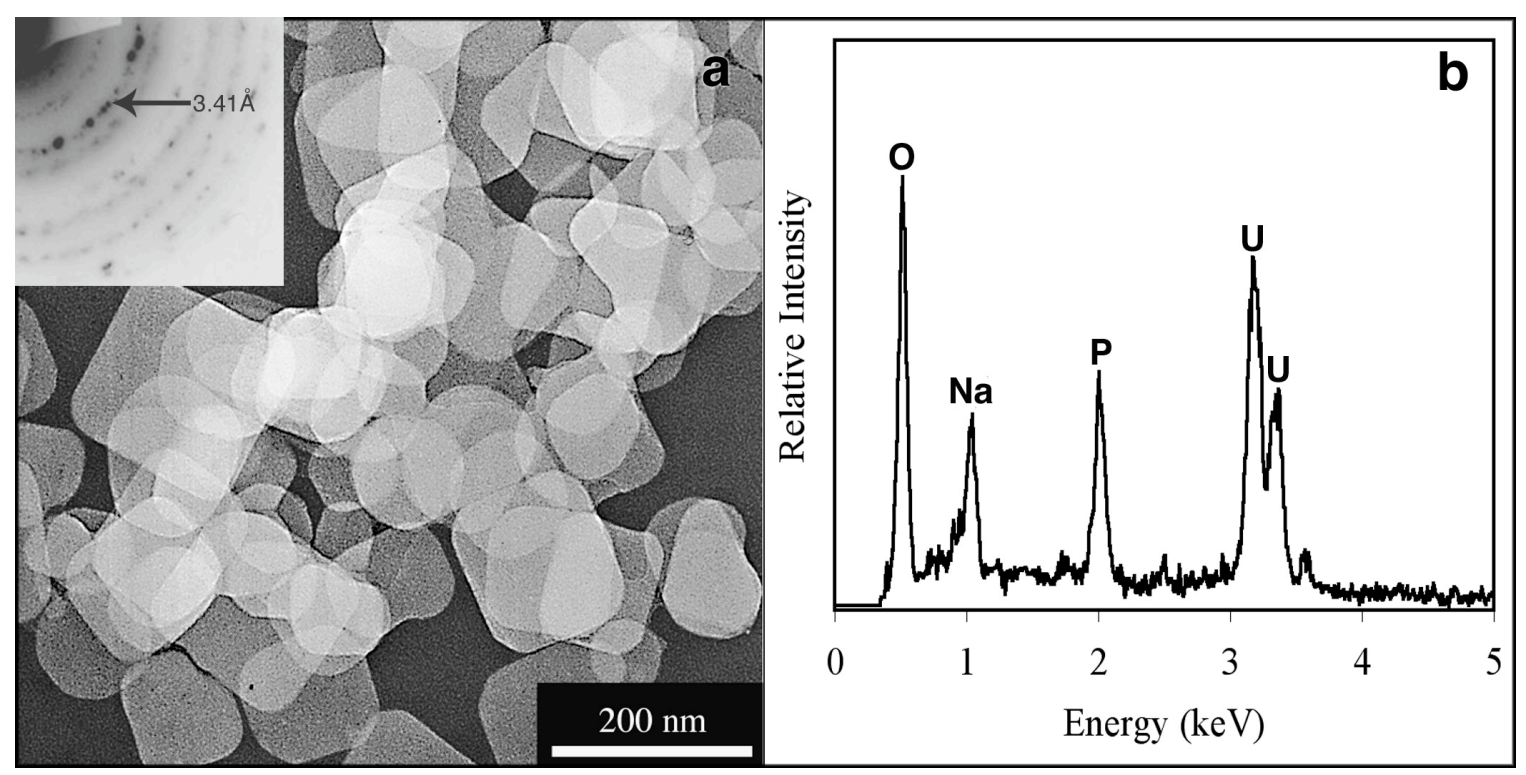

Figure 2

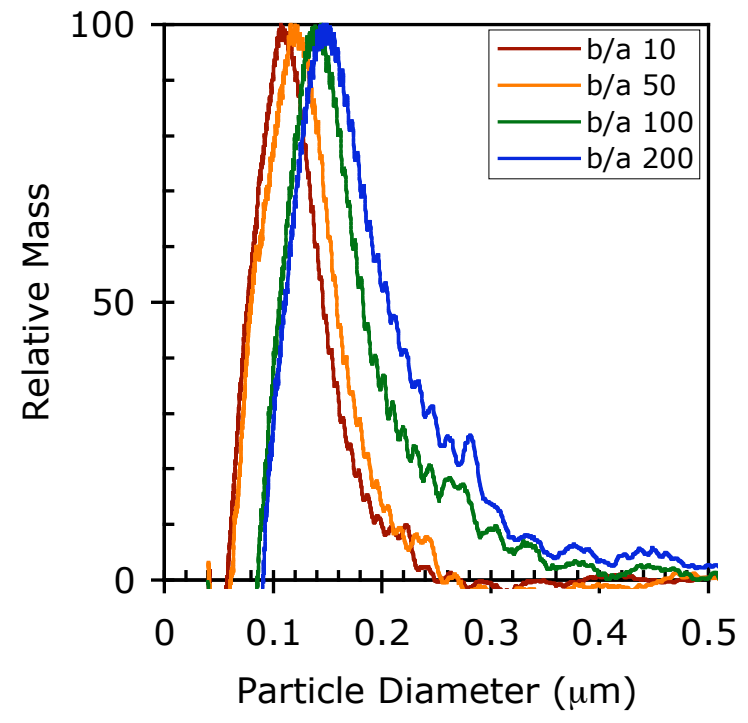


Figure 3

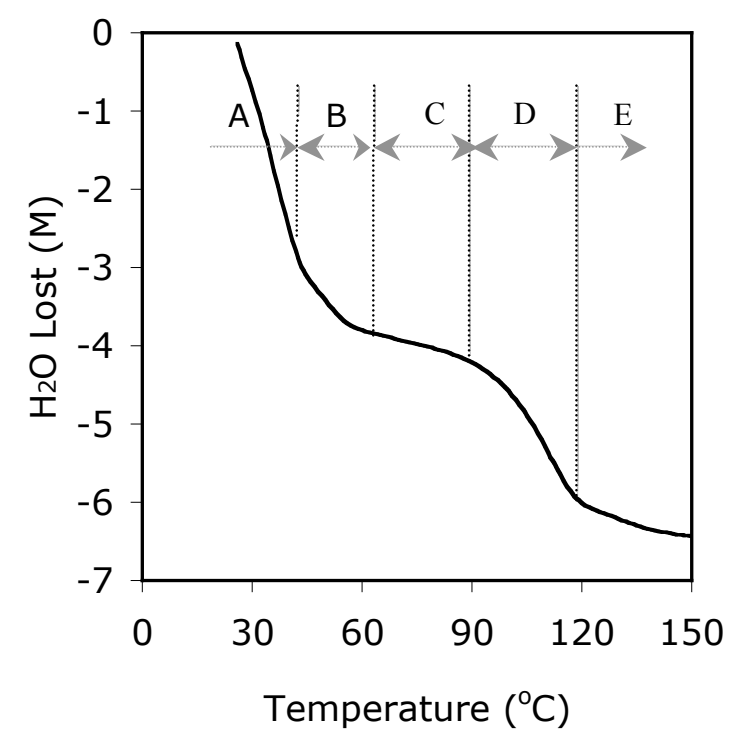

Figure 4

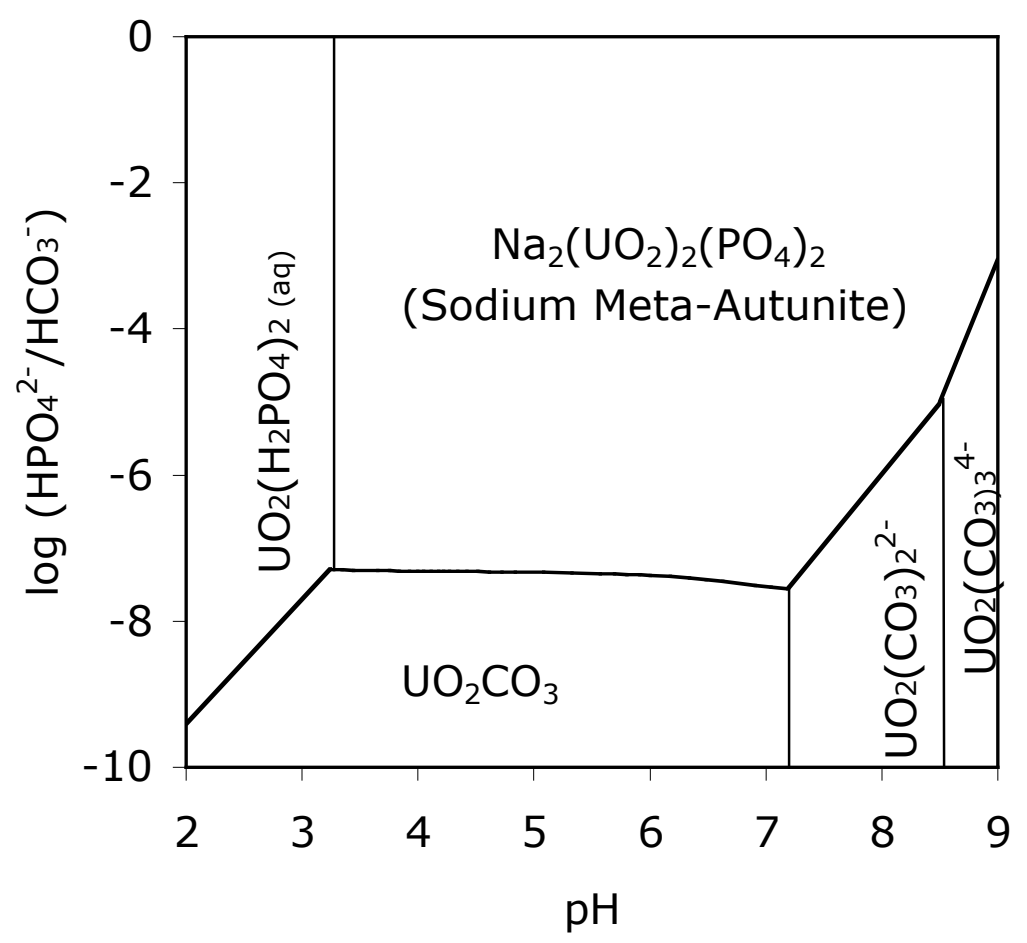


Figure 5
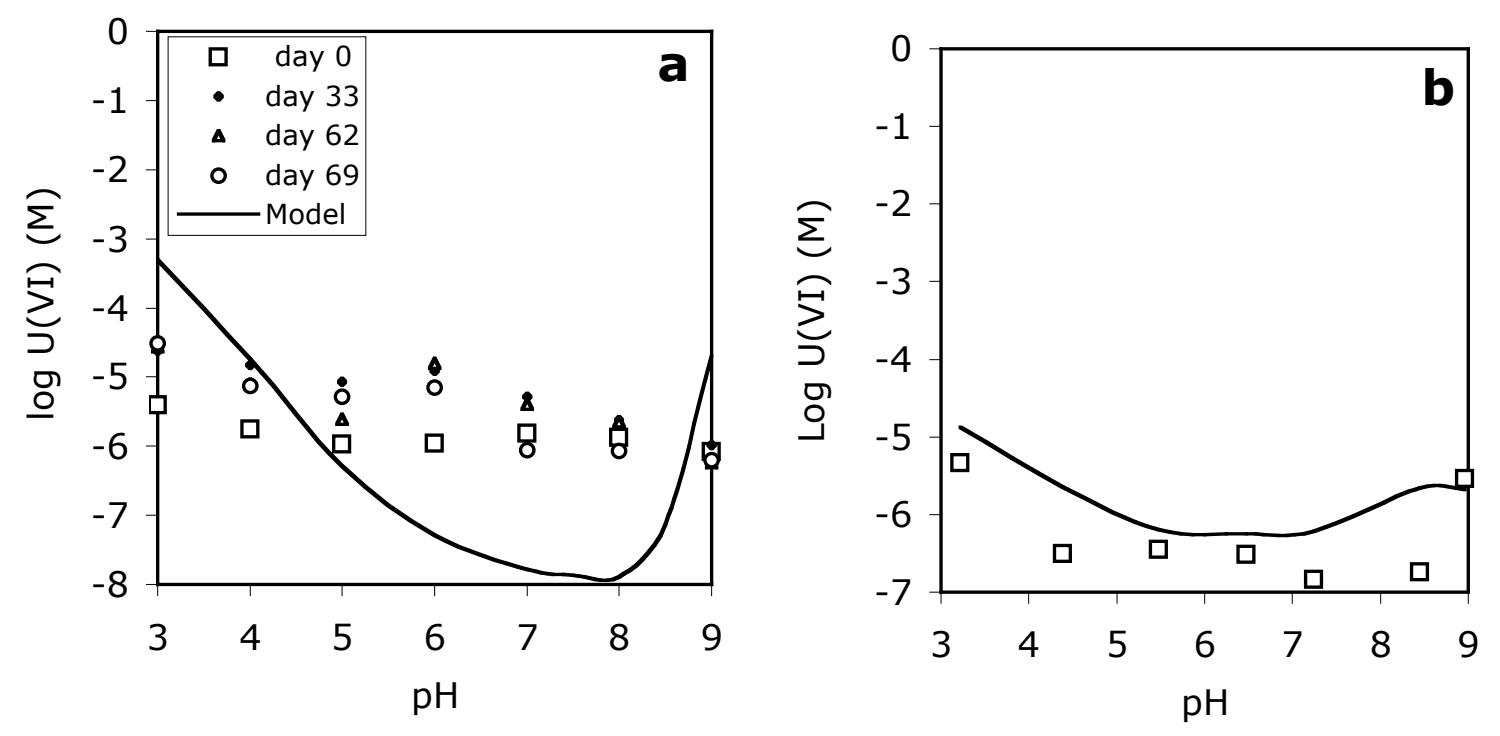

Figure 6

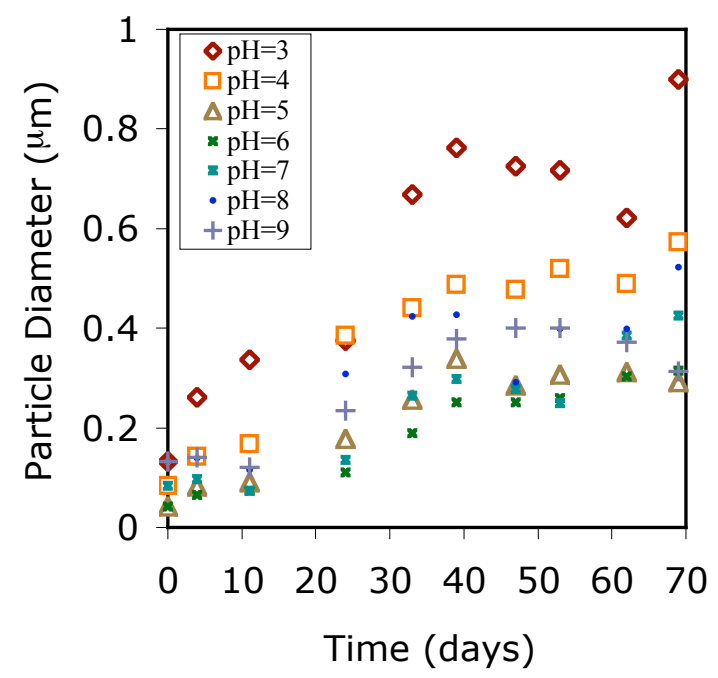


Figure 7
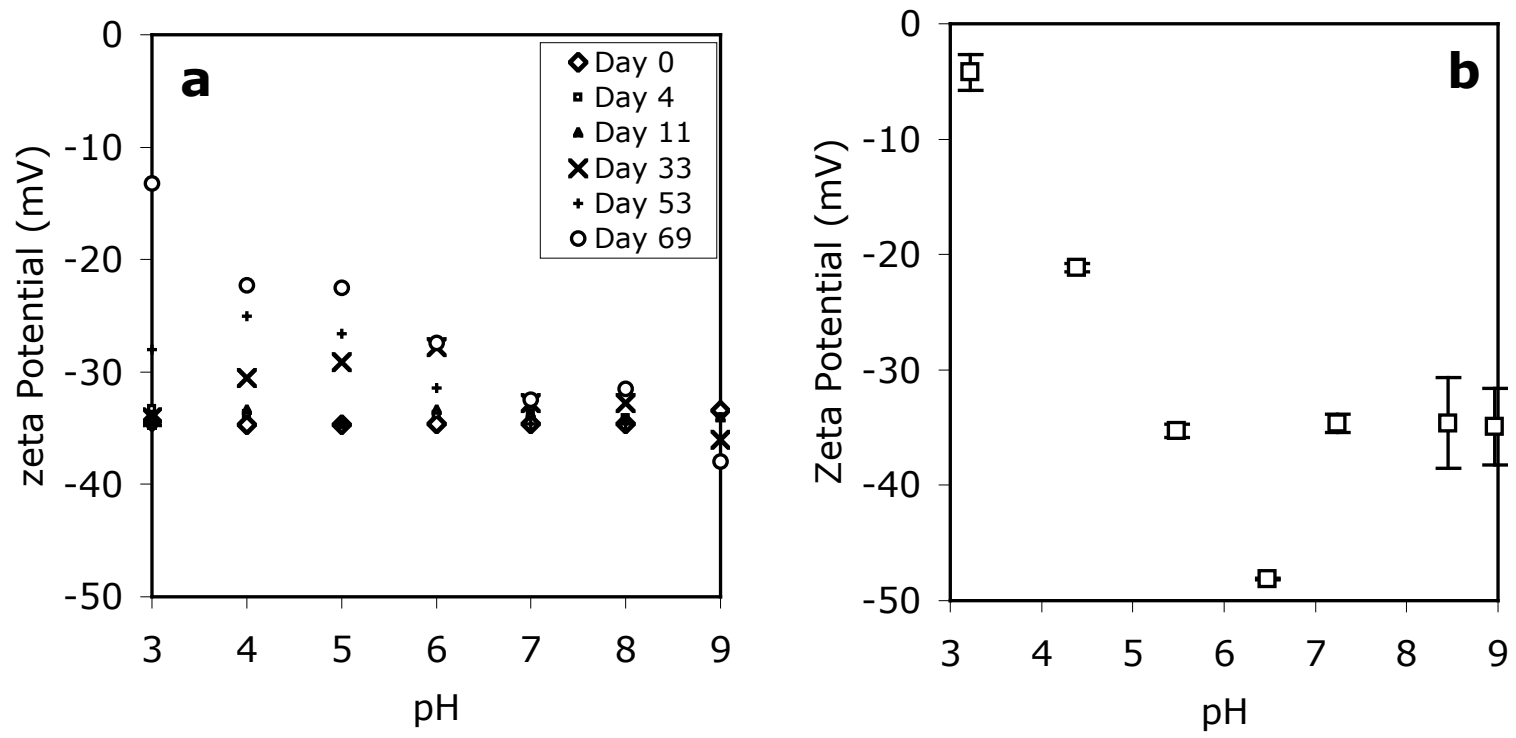

Figure 8
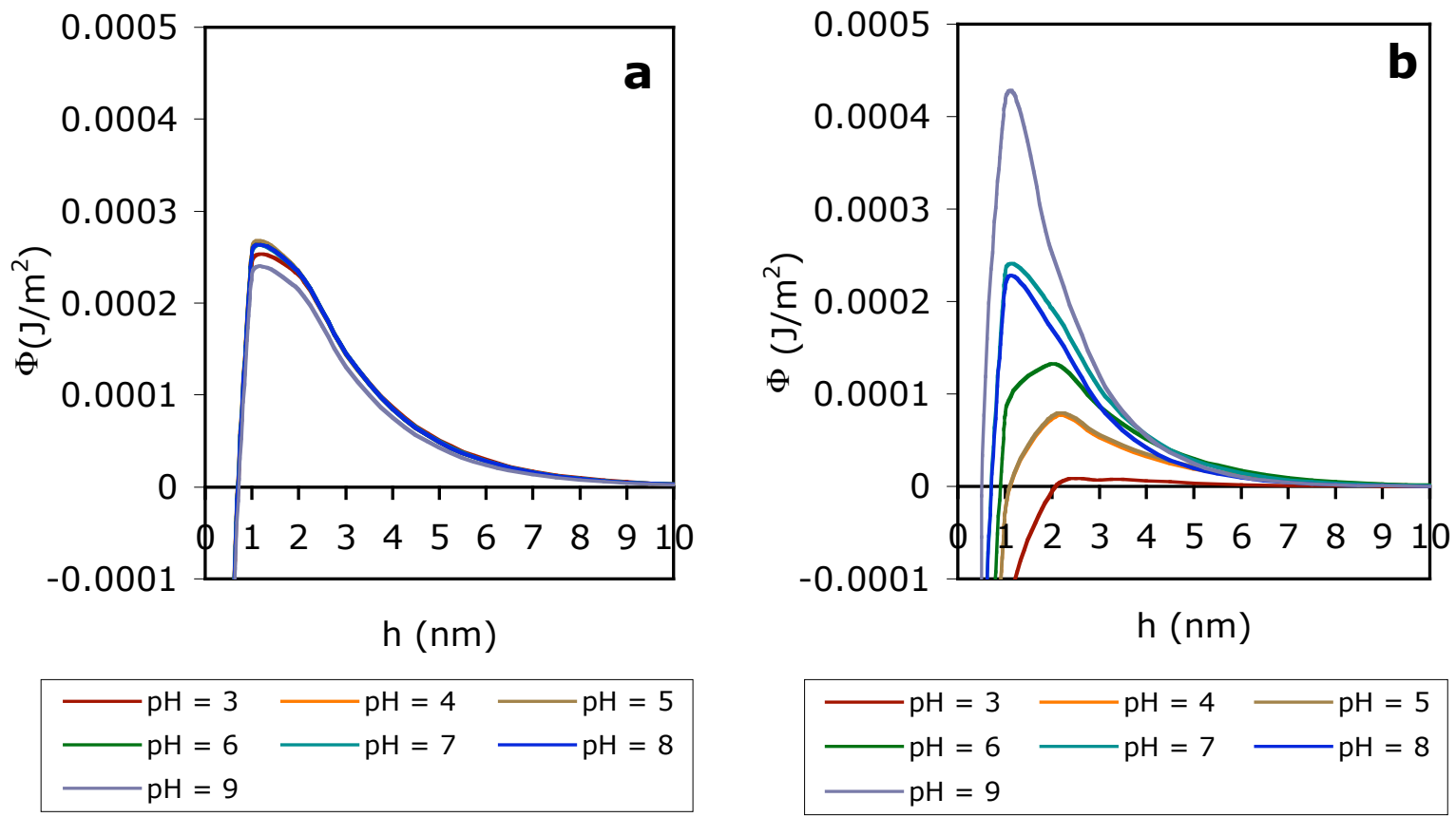